\title{
Gender Differences amongst South African Senior Secondary School Learners' Geometric Thinking Levels
}

\author{
Alex, J.K \\ Faculty of Education, Walter Sisulu University, Private Bag X1, Mthatha 5117, \\ Eastern Cape Province, South Africa \\ Mammen, K.J \\ University of Fort Hare, East London Campus, Private Bag X 9083, East London 5200, \\ Eastern Cape Province, South Africa \\ Corresponding Author Email: jogyalex@yahoo.com
}

\section{Doi:10.5901/mjss.2014.v5n20p1908}

\section{Abstract}

This paper reports on the gender differences in the geometrical thinking levels of South African grade 10 learners and emanates from one part of a larger study. A total of 163 male learners and 196 female learners from five purposively selected schools from Umtata District in South Africa's Eastern Cape Province were involved in the study. Participants' geometrical thinking levels were determined through a multiple choice test. The data were analysed using Microsoft Excel 2007 and IBM SPSS Version 19. The results showed that there was a slight difference in the performance in favour of the female learners in terms of the mean score obtained in the test. Nonetheless, the t-test showed no significant statistical difference between the genders in performance.

Keywords: Geometry; gender differences; acquisition of thinking levels.

\section{Introduction}

The South African government attaches high importance to the learning and teaching of mathematics, science, engineering and technology in its school system due to the significant role which these subjects play in nation building. Geometry is included as part of the South African mathematics curriculum in order for learners to have a wide range of options in choosing careers in mathematics, science, engineering and technology. This paper reports on the gender differences in the geometrical thinking levels of South African grade 10 learners and emanates from one part of a larger study. A total of 163 male learners and 196 female learners from five purposively selected schools from Umtata District in South Africa's Eastern Cape Province were involved in the study.

\subsection{Gender and mathematical achievement}

Gender differences in performance in mathematics have been of ongoing interest to researchers around the globe (see for example, Fennema \& Sherman, 1978; Helwig, Anderson \& Tindal, 2001; Mason, 2003; Watt, 2006; Keller, 2007; Georgiou, Stavrinides \& Kalavana, 2007; Greyling, 2008; Fryer \& Levitt, 2010; Keller, 2007; Ngware, Ciera, Abuya, Oketch \& Mutisya, 2012; Kim \& Law, 2012; Doris, O’Neill \& Sweetman, 2013; Gherasim, Butnaru \& Mairean, 2013).

Interest in gender related differences in academic performance has been stimulated by concerns about the failure of female students to achieve their academic potential and the most widely reported findings in this area suggest that girls tend to do better than boys in English and boys tend to excel in Mathematics (Wentzel, 1998). According to Halat and Sahin (2008), factors such as knowledge of teachers, gender, task difficulty, perception of cognitive competence, perception of parental support, curriculum and environment seem to play vital roles on student achievement and motivation in the mathematics classroom. Springer and Deutsch (1981) suggested that females were superior in verbal tasks than males and males were superior in spatial tasks than females. According to Helwig, Anderson and Tindal (2001), several studies indicate that boys outperform girls when they solve arithmetic and algebraic word problems as well as geometry and other spatially related tasks. Battista (1990) claims that it has been hypothesized that the mathematical processes used by individuals as they learn mathematics or do problem solving depend on some 
underlying mental abilities. Evidence from psychological research also points out that the left hemisphere of the human brain is specialised for logical thinking and reasoning and language efficiency and the right hemisphere is specialised in spatial and artistic tasks (Battista, 1990). It has been suggested by Springer and Deutsch (1981) that gender differences in spatial abilities may be related to the differences in the way that those capabilities are distributed between the cerebral hemispheres in males and females.

Internationally, women were prohibited from pursuing doctoral studies in mathematics at essentially all universities in the world before the 1890s. Hence, their extreme scarcity before the 20th century was largely due to very few women having had the opportunity to develop and use their mathematical talents (Hyde \& Mertz, 2009). McGraw, Lubienski and Strutchens (2006) state that gender related research has gained respect in mathematics research education communities in the United States and despite the efforts by mathematics educators addressing the issues of gender equity, female students remain less likely than male students to persist in the study of mathematics.

Previously, gender differences have been found as one amongst the cognitive and affective predictors of mathematics achievement, including spatial skills and attitudes towards mathematics (Ganley \& Vasilyeva, 2011). In many mathematical achievement measures, boys tended to outperform girls (Hyde, Fennema \& Lamon, 1990). Helwig, Anderson and Tindal (2001) argued that there was a possibility that teachers might acquire incorrect negative perceptions of the mathematical abilities of their female students. According to Halat (2006), it seemed that girls' perceptions of valuing success in mathematics were totally different from those of boys. Fennema and Sherman (1978) also stated that more males than females considered mathematics to be more useful. Females perceived that their teachers were less positive towards them than males as learners of mathematics (Halat, 2006: 174). According to an empirical study conducted in the United States of America by Fryer and Levitt (2010), there was no statistical difference in the gender gap in mathematics at the entry level in school, but girls lost more than two-tenths of a standard deviation as compared to boys in the first six years of schooling.

In Africa also, studies have been conducted in order to find out whether there was a significant relationship between gender and mathematics achievement (Abiam \& Odok, 2006) and gender and interest of students in geometry (Achor, Imoko \& Ajai, 2010). In South Africa also, Atebe (2008) found that male learners performed better than female learners in geometrical achievement. As can be seen from the examples mentioned above, there are on the one hand many studies in the literature which revealed that gender was an important factor in success in mathematics and geometry and on the other hand, there are others that observe that gender was not important.

\subsection{Gender and geometrical achievement}

Several studies investigated gender differences in learning geometry (e.g., Armstrong, 1981; Usiskin, 1982; Battista, 1990; Barnard \& Cronje, 1996; Isiksal \& Askar, 2005; Halat, 2006; Atebe, 2008; Halat \& Sahin, 2008; Viahovic-Stetic, Pavlin-Bernadic \& Rajter, 2010; Yang \& Chen, 2010; Bal, 2014). Yang and Chen (2010) state that among various human factors, spatial abilities and gender differences are critical to geometric learning and gender differences play an important role in geometric learning because boys and girls show different outcomes in different learning environments when they learn geometry (Yang \& Chen, 2010, p.1221). It can be noted that the balance between spatial and logical ability can play a role in geometry performance in general (Battista, 1990). But Bal (2014) argues that attitude is an important predictor in the context of success in geometry and gender is an important factor affecting success due to the fact that cultural factors are dominant over the biological factors. Research findings show that gender differences in mathematics are varied at middle school levels. Evidence on when gender differences in perceptions of competence in mathematics start to occur is not entirely consistent. For example, Fennema and Sherman (1978) found that there was no statistically significant gender related differences in spatial visualization. Also, Halat (2006) cited Armstrong (1981) who stated that there was no difference in the achievement in the sixth grade level of boys and girls in the skills of measurement applications, geometry applications, and probability/statistics. Nevertheless, according to Halat (2006), Armstrong (1981) also posited that thirteen-year-old girls performed better at computation and spatial visualization than boys.

\subsection{The South African context}

Since the inception of democracy in South Africa, one of the greatest achievements has been the massive expansion of access to basic education, especially in the enrolment of girls and the commitment to transforming gender relations, resolve to achieve gender parity, and promotion of women's empowerment (Moloi \& Chetty, 2011). Within the Department of Basic Education (DBE), there is a Gender Equity Unit. According to Moloi and Chetty (2011), the Unit's main function is to monitor gender equality, with particular focus on equal opportunities for both boys and girls and equal 
access to basic education. The Unit also endeavours to:

- girls' retention in school,

- promotion of girls' participation and performance in science and mathematics,

- protection of girls against violence,

- prevention of all kinds of gender biases in the curriculum, and

- promotion of equitable gender advancement in all potential career fields.

The 2001 National Census revealed that amongst the population of twenty years and older, there were twice as many women as men in the social sciences, while there were ten times as many men as women in the engineering and the natural sciences (DoE, 2008). The 2010 Education for All (EFA) Country Report indicated that in 2008 South Africa ranked 22 out of 138 countries that were assessed for gender parity (DoE, 2010).

In terms of the participation of both boys and girls in education, South Africa maintained a reasonably equitable gender balance. Girls achieved at an equal level with boys in many subjects at primary and secondary level while girls did not do as well as boys in Mathematics and Physical Sciences, but their achievements in Biology and English were equivalent (Unterhalter, 2004). There were more female learners in the National Senior Certificate (NSC) examinations from 2008 to 2012, but in general, higher percentages of male than female learners succeeded between 2008 and 2012 (DBE, 2012). Regarding the performance of females and males from 2008 to 2012 in the NSC in Mathematics and Physical Science, the males outperformed females in both subjects, but the gender difference was not significant. This shows that gender difference is far less striking than the achievement levels of both male and female candidates (DBE, 2012). According to the Global Gender Gap Report (2009) cited in the Education For All (EFA, 2013) report, South Africa made great strides in closing gender gaps for its progress to the sixth position.

\section{Thinking Levels in Geometry}

Jones (2002) suggests that geometry helps students to develop skills of visualisation, critical thinking, intuition, perspective, problem-solving, conjecturing, deductive reasoning, logical argument and proof. In the literature, spatial sense, spatial perception, spatial insight, spatial visualisation and spatial orientation have been used for reference to spatial skills in geometric thinking (Bennie, 1998). Spatial ability plays a very important part in the development of geometric concepts and their representations (Nickson, 2000).

In South Africa, one of the aims of teaching mathematics is to develop an understanding of spatial concepts and relationships (DoE, 2003). According to Bennie (1998), the ability to perceive spatial relationships is important for everyday activities like reading maps, playing sports, technical and scientific occupations and the study of mathematics itself as in studying about surface area and volume. Despite geometry being an important branch of mathematics, there are many challenges in teaching and learning it Researchers have documented that many learners encounter difficulties and show poor performance in geometry (King, 2003; Atebe, 2008; Halat, Jakubowski \& Aydin, 2008, Halat \& Sahin, 2008; Alex \& Mammen, 2012). Atebe and Schafer (2009) stated that the teaching and learning of geometry is one of the most disappointing experiences in many schools across nations. Halat (2006) points out that National Council of Teachers of Mathematics (NCTM, 2000) recommends that new educational theories and approaches should be used in teaching to help students to overcome their difficulties in mathematics.

\subsection{The van Hiele theory}

How children develop their understanding of geometry and their spatial sense has been an area of research over the past 60 years (Usiskin, 1982; Burger \& Shaughnessy, 1986; Fuys, Geddes \& Tischler, 1988; Clements \& Battista, 1992; King, 2003; Atebe, 2008). One of the models that were proposed in the 1950's was the theoretical perspective put forward by two Dutch mathematicians, Pierre van Hiele and his wife Dina van Hiele-Geldof (Alex, 2012). Due to their experience in classroom teaching in the Netherlands in the 1950s, the husband and wife van Hiele team (Pierre van Hiele and Dina van Hiele - Geldof) put forward a theoretical perspective for the teaching and learning of geometry, which is universally referred to as the van Hiele theory (Pegg \& Davey, 1998). This model of thought levels provides useful empirically-based descriptions of what are likely to be relatively stable, qualitatively different, stages or levels of understanding in learners (Ding \& Jones, 2007). The most prominent feature of the model is a five level hierarchy of ways of understanding spatial ideas (van Hiele, 1986). Each of these five levels (levels 1 - 5) describes the thinking processes used in geometric contexts (van de Walle, 2001).

Van Hiele levels of geometric thinking can be summarised as in Table1 below. 
Table 1: Van Hiele levels of geometric thinking

\begin{tabular}{|lll|}
\hline Levels & Known as & Description: Learner will be able to \\
\hline Level 1 & Visualization & recognise and name figures \\
Level 2 & Analysis & describe the attributes of shapes \\
Level 3 & Ordering & classify and generalise by attributes \\
Level 4 & Deduction & develop proofs using axioms and definitions \\
Level 5 & Rigor & work in various geometrical systems \\
\hline
\end{tabular}

Meanwhile, as a result of learners not achieving even the basic level (level 1), such as 'not yet at level 1' or 'weak level 1', researchers have suggested and used the introduction of another level, called level 0 (pre-recognition level) (for example, see Usiskin, 1982; Halat, 2007; Atebe, 2008; Alex, 2012). Clements and Battista (1992, p.429) point out that "the bulk of the evidence from the van Hiele-based research along with research from the Piagetian perspective, indicated the existence of thinking more primitive than, and probably prerequisite to, van Hiele's level 1". They named this level 0 as "pre-recognition". They defined it as "children initially perceive geometric shapes, but may attend to only a subset of a shape's visual characteristics and they are unable to identify many common shapes" (Clements \& Battista, 1992, p.429). In this study, the existence of level 0 was taken into consideration in the assignment of the van Hiele levels to the learners who participated in the study. Progression from one level to the next is not the result of maturation or natural development. It is the quality and nature of the experience in the teaching and learning program that influences a genuine advancement from a lower to a higher level (van Hiele, 1986).

The theory also offers a model of teaching that teachers can apply in order to promote their learners' levels of understanding of geometry (Atebe, 2008). According to Usiskin (1982, p.12), the theory is considered to be one of the best for the teaching and learning of geometry because it possesses three appealing characteristics such as "elegance, comprehensiveness and wide applicability".

\section{Research Methodology}

Five schools were purposively selected from Umtata District in South Africa's Eastern Cape Province. The participants were selected using the convenience sampling procedure as suggested by McMillan and Schumacher (2006). Accordingly, two classes of learners from five different schools were selected on the basis of availability and accessibility. The study utilised grade 10 learners as the sample because most of the literature available discusses the van Hiele Theory in terms of polygons and these are included only in the grade 10 syllabus.

Although the van Hiele model was developed in the 1950s, it became popular only in the 1970s in the United States (Wirszup, 1976; Hoffer, 1983). According to Atebe (2008), Usiskin developed the van Hiele Geometry Test in 1982 which became known as Cognitive Development and Achievement in Secondary School Geometry (CDASSG) to test the theory and since then, both the test and theory got refined and thousands of learners got tested with it. The test which was constructed by the staff of the CDASSG project, and adapted by Atebe (2008) which he called van Hiele Geometry Test, (VHGT), was in turn adopted for this study with his permission. The VHGT was used to determine the van Hiele level of geometric thinking. This was in accordance with van Hiele (1986) who suggested that the studies that investigate the geometric thinking levels should be content specific. The VHGT was on basic geometrical content (space and shape) in the senior secondary schools. The focus was on topics of basic geometric concepts like identification, classification and properties of triangles and quadrilaterals and angle measurement, angle sums of lines, triangles and quadrilaterals.

The VHGT was a multiple choice test which comprised of four subtests. Each subtest consisted of five items based on one van Hiele level and therefore there were 20 items in the test, with item numbers 1-5, 6-10, 11-15, and 16-20 for testing learner's attainment of van Hiele levels 1, 2, 3, and 4 respectively. Each correct response in the test was given 1 mark. Hence, each learner's total score was between 1 and 20 in the VHGT. The percentage mean score was calculated using Microsoft Excel 2007. The grading of the VGHT was done again using a second method which was based on the ' 3 of 5 correct" success criterion as suggested by Usiskin (1982, p.22). By this criterion, if a learner answers correctly at least 3 out of 5 items in any of the 4 subtests within the VHGT, the learner was considered to have mastered that level. According to this grading system the learners' scores were weighted as follows:

1 point for meeting criterion on item 1-5 (level 1)

2 points for meeting criterion on item 6-10 (level 2)

4 point for meeting criterion on item 11 - 15 (level 3)

8 point for meeting criterion on item 16-20 (level 4) 
This made the maximum score for any learner to be $1+2+4+8=15$ points. This weighted sum helped to determine the van Hiele levels upon which the criteria were met from the weighted sum alone. For example, a score of 7 indicated that the learner met the criteria at levels 1,2 and 3 (i.e., 1+2+4 =7). This grading system helped to assign the learners into various van Hiele levels based on their responses. The weighted sum and the corresponding levels were as shown below.

Again, a weighted sum of 0 indicated that a learner has not achieved any levels, as the learner did not get at least 3 out of any subtests of the VHGT. This learner was operating at a lower level known as level 0 or pre-recognition level. A weighted sum of 2 indicated that the learner achieved at least 3 out of 5 only at level 2. But, because of skipping level 1 , the learner was classified under level 0 . In the same way, a learner with a weighted sum of 4 or 8 was also at level 0 because of skipping levels 1 and 2 for the weighted sum of 4 or levels 1,2 and 3 for the weighted sum of 8 .

\section{Results}

The results of the first set of analysis on the percentage mean score are shown in Table 2.

Table 2: Percentage mean score of male and female learners

\begin{tabular}{|lcc|}
\hline \multirow{2}{*}{ School } & \multicolumn{2}{c|}{ Percentage mean score in the VHGT } \\
& Male & Female \\
\hline School A & 34.00 & 34.79 \\
School B & 30.97 & 32.56 \\
School C & 26.60 & 27.19 \\
School D & 42.50 & 37.44 \\
School E & 31.92 & 33.46 \\
Overall Percentage Mean & 32.42 & 33.47 \\
\hline
\end{tabular}

The percentage mean score was slightly higher for female learners in all schools except in School D where the percentage mean score of male learners was higher than that of female learners. In order to check whether there was a statistical difference in the performance of the two groups, a t-test was performed using IBM SPSS version 19.

Table 3: Statistical comparison of the percentage mean score of male and female learners

\begin{tabular}{|lcccccc|}
\hline Gender & Number & \% Mean Score & Standard Deviation & $d f$ & t-value & $p$-value \\
\hline Male & 163 & 32.42 & 11.91 & \multirow{2}{*}{357} & \multirow{2}{*}{0.855} & \multirow{2}{*}{0.197} \\
Female & 196 & 33.47 & 11.24 & & & \\
\hline
\end{tabular}

Table 3 showed that in the entire sample, there was a slight difference in the performance in the test in favour of the female learners. Male learners obtained a percentage mean score of $32.42 \%$ and female learners obtained a percentage mean score of $33.47 \%$. This test of significance indicated that the difference in the percentage mean scores between the male learners and female learners of the entire study sample was not statistically significant. This means that the male learners and female learners in the entire study sample were similar in their performance.

Table 4 below shows the percentage of learners in each van Hiele level from each of the schools.

Table 4: The number and percentage of male and female learners at each van Hiele level

\begin{tabular}{|c|c|c|c|c|c|c|c|c|c|c|c|c|c|c|c|c|c|c|c|c|}
\hline \multirow{3}{*}{ Levels } & \multicolumn{4}{|c|}{ School A } & \multicolumn{4}{|c|}{ School B } & \multicolumn{4}{|c|}{ School C } & \multicolumn{4}{|c|}{ School D } & \multicolumn{4}{|c|}{ School E } \\
\hline & \multicolumn{2}{|c|}{ Male } & \multicolumn{2}{|c|}{ Female } & \multicolumn{2}{|c|}{ Male } & \multicolumn{2}{|c|}{ Female } & \multicolumn{2}{|c|}{ Male } & \multicolumn{2}{|c|}{ Female } & \multicolumn{2}{|c|}{ Male } & \multicolumn{2}{|c|}{ Female } & \multicolumn{2}{|c|}{ Male } & \multicolumn{2}{|c|}{ Female } \\
\hline & $\mathrm{N}$ & $\%$ & $\mathrm{~N}$ & $\%$ & $\mathrm{~N}$ & $\%$ & $\mathrm{~N}$ & $\%$ & $\mathrm{~N}$ & $\%$ & $\mathrm{~N}$ & $\%$ & $\mathrm{~N}$ & $\%$ & $\mathrm{~N}$ & $\%$ & $\mathrm{~N}$ & $\%$ & $\mathrm{~N}$ & $\%$ \\
\hline 0 & 14 & 18 & 28 & 36 & 45 & 42 & 22 & 20 & 18 & 31 & 22 & 39 & 2 & 3 & 17 & 26 & 20 & 38 & 14 & 27 \\
\hline 1 & 11 & 14 & 7 & 9 & 11 & 10 & 18 & 17 & 7 & 12 & 8 & 14 & 6 & 9 & 16 & 24 & 2 & 4 & 5 & 10 \\
\hline 2 & 5 & 6 & 13 & 17 & 6 & 6 & 5 & 5 & 0 & 0 & 2 & 4 & 11 & 17 & 9 & 14 & 4 & 8 & 7 & 13 \\
\hline 3 & 0 & 0 & 0 & 0 & 0 & 0 & 0 & 0 & 0 & 0 & 0 & 0 & 1 & 2 & 3 & 5 & 0 & 0 & 0 & 0 \\
\hline 4 & 0 & 0 & 0 & 0 & 0 & 0 & 0 & 0 & 0 & 0 & 0 & 0 & 0 & 0 & 0 & 0 & 0 & 0 & 0 & 0 \\
\hline Total & 30 & 38 & 48 & 62 & 62 & 58 & 45 & 42 & 25 & 43 & 32 & 57 & 20 & 31 & 45 & 69 & 26 & 50 & 26 & 50 \\
\hline
\end{tabular}


It was found that most of the learners in all the schools were at level 0,1 or 2 irrespective of gender. Only $2 \%$ of male learners and $5 \%$ of female learners from School $D$ were the only learners operating at level 3 . The percentages of learners at level 2 were higher for female learners in all the schools except in Schools B and D (School A: 17\%; School C: 0\%; and School E: 13\%) against their male counterparts (School A: 6\%; School C: 4\%; and School E: 8\%). In Schools B and $D$ the percentages of male learners at level 2 were $1 \%$ and $3 \%$ higher than that of female learners. The percentages of learners at level 1 were higher for female learners in all the schools except School A (School B: 17\%; School C: 14\%; School D: 24\% and School E: 10\%) against their male counterparts (School B: 10\%; School C: 12\%; School D: 9\% and School E: 4\%). The percentages of learners at level 0 were higher for female learners in all the schools except Schools B and E (School A: 36\%; School C: 39\% and School D: $26 \%$ ) against their male counterparts (School A: 18\%; School C: $31 \%$ and School D: $3 \%$ ). The percentages of female learners were higher at the lower levels in most of the schools indicated that the performance of female learners was lower than that of the male learners. It can be assumed that even though it appears that higher order thinking levels were mostly achieved by female learners, the statistical inference shows that the overall achievement in the VHGT was independent of gender or gender did not play a role in the performance of the entire sample.

\section{Discussion}

In School D, male learners performed slightly better than the female learners and in School A, School B, School C and School E, the female learners' performances were slightly better. The test of significance indicated that the differences in the percentage mean scores between the male learners and female learners in each school and all schools combined were not statistically significant at the 0.05 level of significance. It can be assumed that the overall achievement in the VHGT was independent of gender. Gender did not play a role in the performance of the entire sample. Since the VHGT tested both spatial and verbal skills, it can be assumed that gender differences could not play a role as females are superior in verbal tasks than in males and males are superior in spatial tasks than females.

This negligible difference in favour of female learners was not consistent with the previous studies as Atebe (2008) noticed a marginal difference of $4 \%$ in favour of male learners who obtained a percentage mean score of $38 \%$, while the female learners obtained only a percentage mean score of $34 \%$ in his sample of South African High School learners. Nevertheless, in a study by Halat (2006) in Turkey, a sample of 150 learners (66 male learners and 84 female learners) from grade 6 was tested on the acquisition of van Hiele levels and it was found that there was no statistically significant gender difference detected in the performance. This was also consistent with Usiskin's (1982) study on American learners, where there was no statistically significant gender difference in the fall test results (carried out at the beginning of the school year). But in the spring test results (carried out at the end of the school year), were in favour of the male learners. Yang and Chen's (2010) study with 18 boys and 16 girls from $5^{\text {th }}$ grades in Taiwan on the effect of gender differences and spatial abilities within a digital pentominoes game where a pre-test/post-test design was used, they inferred that gender differences existed in the beginning favouring boys, but in the post test there were no significant gender differences in spatial abilities. Battista (1990) reported gender differences in both geometrical and spatial thinking and in interrelationships between student abilities and their geometric achievement in favour of male learners.

The study conducted by Helwig, Anderson and Tindal (2001) on mathematical skills achievement of 512 students from Oregon established that mathematics and reading achievement scores were similar in both male and female students. Achor, Imoko and Ajai's study (2010) in Nigeria with a sample of 158 boys and 129 girls in 46 senior secondary schools revealed that male and female students who were taught using games and simulations did not differ significantly both in interest and achievement in geometry. The results from the study conducted by Bal (2014) which consisted of 1270 primary school learners also revealed that there was no significant relationship between the gender and geometric thinking variables. The results of the present study also support the findings of researchers (for example, Fennema \& Hart, 1994; Halat, 2006; Yang \& Chen, 2010; Bal, 2014) who either claim a considerable decrease in gender difference or no significant gender difference in learners' achievements in geometry or mathematics in recent years.

\section{Findings, Conclusions and Implications}

Learners of both gender showed similar thinking levels in geometry from the van Hiele Geometry Test. The results in this study support the observations that a either a considerable decrease in gender difference or no significant gender difference is traceable in learners' achievements in geometry or mathematics in recent years.

The results of the study revealed that the levels of thinking were lower than what was expected of the learners who participated in the study. The low geometry knowledge might be due to the inadequate geometrical experiences from the 
lower grades. Furthermore, the study found that although the mean score of female learners' van Hiele levels was higher than that of males, this difference was not statistically significant. In other words, both female and male learners performed equally on the test. This is confirmatory with respect to reports from researchers such as Fennema and Hart (1994), Halat (2006), Yang and Chen (2010), and Bal (2014). Nonetheless, it is in disagreement with reports from Usiskin (1982), Battista (1990) and Atebe (2008). It is particularly interesting to note that this study's results are in variance with that of Atebe (2008) who conducted a similar study in another area of the same province in South Africa.

This study's result takes out the myth that mathematics is a male domain. Female learners should maintain their confidence in learning geometry. Educators need to motivate female learners by telling them that they can also master geometry like any other topic in mathematics. Co-educational institutions should foster healthy competition between different genders in achievement in geometry in particular and mathematics in general. Male and female learners need to collaborate and learn to gain from one another to better their geometric academic achievement.

\section{References}

Abiam, P.O., \& Odok, J.K. (2006). Factors in students' achievement in different branches of secondary school mathematics. Journal of Education and Technology, 1(1), 161-168.

Achor, E., Imoko, B.I., \& Ajai, J.T. (2010). Sex differentials in students' achievement and interest in geometry using games and simulations technique. Necatibey Faculty of Education Electronic journal of Science and mathematics Education, 4(1), 1-10.

Alex, J.K. (2012). The evaluation of an instructional framework using van Hiele levels for learning andteaching geometry in five rural senior secondary schools. Unpublished Doctoral thesis. Walter Sisulu University, South Africa.

Alex, J.K., Mammen, K.J. (2012). A survey of South African grade 10 Learners' geometric thinking levels in terms of the van Hiele theory. Anthropologist, 14(2), 123-129.

Armstrong, J.M. (1981). Achievement and participation of women in mathematics: results of two national surveys: Journal for Research in Mathematics Education, 12(5), 356-372.

Atebe, H.U. (2008). Students' van Hiele levels of geometric thought and conception in plane geometry: A collective case study of Nigeria and South Africa. Unpublished Doctoral thesis, Rhodes University, South Africa.

Atebe, H.U., \& Schafer, M. (2009). The face of geometry instruction and learning opportunities in selected Nigerian and South African high schools: Proceedings of the 17th Annual Conference of the Southern African Association for Research in Mathematics, Science and Technology Education (SAARMSTE), January 2009. Rhodes University, South Africa.

Bal, A.P. (2014). Predictor variables for primary school students related to van Hiele geometric thinking. Journal of Theory and Practice in Education, 10(1), 259-278.

Barnard, J.J., \& Cronje, L.S. (1996). Euclidean geometry: Cognitive gender differences. South African Journal of Education, 16 (1), 1-4.

Battista, M.T. (1990). Spatial visualization and gender differences in high school geometry.Journal for Research in Mathematics Education, 21(2), 47-60.

Bennie, K. (1998). "Space and shape" - An approach to the study of geometry in the intermediate phase. Proceedings of $4^{\text {th }}$ annual congress of the association for Mathematics education of South Africa (AMESA) Pietersburg, July 1998. South Africa.

Burger, W.F., \& Shaughnessy, J.M. (1986). Characterizing the van Hiele levels of development in geometry. Journal for Research in Mathematics Education, 17, 131-148.

Clements, D.H., \& Battista, M. (1992). Geometry and spatial reasoning. In: Grouws, D.A. ed. Handbook of research on Mathematics teaching and Learning, New York:

Department of Basic Education. (2012). National Senior Certificate Examination: Technical Report. Pretoria.

Department of Education (DoE). (2003). Learning programme guidelines. Pretoria: Seriti Printing.

Department of Education(DoE). (2008). National Curriculum Statement Grades 10-12 (general). Learning programme guidelines. Pretoria: Seriti Printing.

Department of Education(DoE). (2010). Education for All country report. Pretoria: Government of South Africa.

Ding, L., \& Jones, K. (2007). Using the van Hiele theory to analyse the teaching of geometrical proof at grade 8 in Shanghai. European Research in Mathematics Education V.

Doris, A., O' Neill, D., \& Sweetman, O. (2013). Single sex schooling and maths achievement. Economics of Education Review, 35, 104-119.

Education for All (EFA). (2013). Country Progress Report: South Africa.

Fennema, E., \& Hart, L.E. (1994). Gender and the JRME. Journal for Research in Mathematics Education, 25(6), 648-659.

Fennema, E., \& Sherman, J.A. (1978). Sex related differences in mathematics achievement factors: A further Study. Journal for Research in Mathematics Education, 9, 189 -203.

Fryer, R. G., \& Levitt, S.D. (2010). An empirical analysis of the gender gap in mathematics. American Economic Journal: Applied Economics, 2(2), 210-240.

Fuys, D., Geddes, D., \& Tischler, R. (1988). The van Hiele model of thinking in geometry among adolescents. Journal for Research in Mathematics education: Monograph 3. VA: NCTM: Reston.

Ganley, C. M., \& Vasilyeva, M. (2011). Sex differences in the relation between math performance, spatial skills, and attitudes. Journal of Applied Developmental Psychology, 32, 235-242.

Georgiou, S.N., Stavrinides, P., \& Kalavana, T. (2007). Is Victor Better than Victoria at Maths? Educational Psychology in Practice, 23(4), 329-342. 
Gherasim, L.R., Butnaru, S., \& Mairean, C. (2013). Classroom environment, achievement goals and maths performance: gender differences. Educational Studies, 39(1), 1-12.

Grayling, A.C. (2008). Mindfields: Maths in school should be cool. New Scientist, 200 (2679), 48-48.

Halat, E. (2006). Sex related differences in the acquisition of the van Hiele levels and motivation in learning geometry. Asia Pacific Education Review, 7(2), 173-183.

Halat, E. (2007). Reform based curriculum \& acquisition of the levels. Eurasia Journal of Mathematics, Science and Technology Education, 3(1), 41-49.

Halat, E., Jakubowski, E., \& Aydin, N. (2008). Reform based curriculum and motivation in geometry. Eurasia Journal of Mathematics, Science and Technology Education, 4(3), 285- 292.

Halat, E., \& Sahin, O. (2008). Van Hiele levels of pre- and in- service Turkish elementary school teachers and gender related differences in geometry. The Mathematics Educator, 11(1/2), 143-158.

Helwig, R., Anderson, L., \& Tindal, G. (2001). Influence of elementary student gender on teacher perceptions of Mathematics achievement. The journal of Educational Research, 95(2), 93-102.

Hoffer, A. (1983). Van Hiele-based research. In: Lesh, R. \& Landau, M. eds. Acquisition of mathematics concepts and processes, 205227. New York: Academic Press.

Hyde, J.S., Fennema, E., \& Lamon, S.J. (1990). Gender differences in mathematics performance: A meta- analysis. Psychological Bulletin, 107, 139-155.

Hyde, J. S., \& Mertz , J. E. (2009). Gender, culture, and mathematics performance. Proc Natl Acad Sci U S A, 106(22), $8801-8807$.

Isiksal, M., \& Askar, P. (2005). The effect of spreadsheet and dynamic geometry software on the achievement and self-efficacy of $7^{\text {th }}$ grade students. Educational Research, 47(3), 333-350

Jones, K. ( 2002). Issues in the teaching and learning of geometry. In: Hagarty, L. ed. Aspects of teaching secondary mathematics: Perspectives on practice, 12-139.

Keller, J. (2007). Stereotype threat in classroom settings: the interactive effect of domain identification, task difficulty and stereotype threat on female students' maths performance. British Journal of Educational Psychology, 77(2), 323-338.

Kim, D.H., \& Law, H. (2012). Gender gap in maths test scores in South Korea and Hong Kong: role of family background and single-sex schooling. International Journal of Educational Development, 32(1), 92-103.

King, L.C.C. (2003). The development, implementation and evaluation of an instructional model to enhance students' understanding of primary school geometry. Unpublished Doctoral thesis, Curtin University of Technology. Perth.

Mason, L. (2003). High school students' beliefs about maths, mathematical problem solving, and their achievement in maths: a crosssectional study. Educational Psychology, 23 (1), 73-84

McGraw, R., Lubienski, S.T., \& Strutchens, M.E. (2006). A closer look at gender in NAEP mathematics achievement and affect data: intersections with achievement, race / ethnicity and socio economic status. Journal for Research in Mathematics Education, 17(2), 129-150.

McMillan, J.H., \& Schumacher, S. (2006). Research in education-evidence based inquiry. $6^{\text {th }}$ ed. USA: Pearson Education, Inc.

Moloi, M.Q., \& Chetty, M. (2011). Progress in Gender Equality in Education: South Africa.

National Council of Teachers of Mathematics (NCTM). (2000). Principles and standards for school mathematics. Reston: VA.

Ngware, M.W., Ciera, J., Abuya, B.A., Oketch, M., \& Mutisya, M. (2012). What explains gender gaps in maths achievement in primary schools in Kenya? London Review of Education, 10(1), 55-73.

Nickson, M. (2000). Teaching and Learning Mathematics. A teacher's guide to recent research. London: Cassell, Wellington House.

Pegg, J., \& Davey, G. (1998). Interpreting Student Understanding in Geometry: a synthesis of two models. In Lehrer, $R$ \& Chazan, D.eds. Designing learning environments for developing understanding of geometry and space, 109-133. New Jersey: Lawrence Erlbaum Associates, Publishers.

Springer, S.P., \& Deutsch, G. (1981). Left brain, right brain. New York: W.H.Freeman.

Unterhalter, E. (2004). Gender equality and education in South Africa: measurements, scores and strategies. Paper delivered at British Council/HSRC conference, Gender Equity In Education, Cape Town.

Usiskin, Z. (1982). van Hiele levels and achievement in secondary school geometry.(Final report of the cognitive development and achievement in secondary school geometry project) Chicago: University of Chicago (ERIC Document Reproduction service Number ED220288).

Van de Walle, J.A. (2001). Elementary and Middle School Mathematics-Teaching Developmentally. $4^{\text {th }}$ ed. Boston: Pearson Education.

Van Hiele, P.M. (1986). Structure and insight: A Theory of Mathematics Education. New York: Academic Press.

Viahovic- Stelic, V., Pavlin- Bernardic, N., \& Rajter, M. (2010). Illusion of Linearity in geometry: Effect in multiple choice problems. Mathematical Thinking and Learning, 12(1), 54-67.

Watt, H.M.G. (2006). The role of motivation in gendered educational and occupational trajectories related to maths. Educational research \& Evaluation, 12(4), 305-322.

Wentzel, K.R. (1998). Social relationships and motivation in middle school: the role of parents, teachers and peers. Journal of Educational Psychology, 90(2), 202-209.

Wirszup, I. (1976). Breakthrough in the psychology of learning and teaching mathematics. In: Martin, J.L. ed. Space and geometry: papers from a research workshop. ERIC, Columbus, USA, 75-97.

Yang, J. C., \& Chen, S.Y. ( 2010). Effects of gender differences and spatial abilities within a digital pentominoes game. Computers and Education, 55(2010), 1220-1233. 